\title{
An Update in Management of Noncutaneous T-Cell Lymphomas
}

\author{
Y. Y. Hwang and R. H. S. Liang \\ Division of Haematology, Department of Medicine, Queen Mary Hospital, The University of Hong Kong, Pokfulam, Hong Kong
}

Correspondence should be addressed to R. H. S. Liang, rliang@hkucc.hku.hk

Received 31 August 2010; Accepted 28 October 2010

Academic Editor: F. M. Foss

Copyright ( 2010 Y. Y. Hwang and R. H. S. Liang. This is an open access article distributed under the Creative Commons Attribution License, which permits unrestricted use, distribution, and reproduction in any medium, provided the original work is properly cited.

T-cell lymphoma is a heterogeneous group of diseases. Except for ALK positive anaplastic large cell lymphoma, T-cell lymphoma responds to conventional chemotherapy unfavourably, and most patients carry poor prognosis. In recent years, efforts have been made to improve the outcome of T-cell lymphoma patients. Novel agents, high-dose therapy, and allogeneic stem cell transplantation are studied, and various results are reported in literature. This paper looks into the prognostication and treatment approach of different entities of noncutaneous T-cell lymphoma and would focus on the latest updates in its management.

\section{Introduction}

T-cell lymphoma accounts for 10 to 15 percent of all non-Hodgkin lymphomas worldwide. In the latest WHO classification of Tumours of Haematopoietic and Lymphoid Tissues, there are altogether nineteen mature T-cell lymphoid malignancies [1]. All of them carry poor prognosis with the notable exception of anaplastic lymphoma kinase (ALK)positive anaplastic large cell lymphoma. They in general respond poorly to conventional chemotherapy with the reported 5-year overall survival (OS) rate and event-free survival (EFS) rate of $41 \%$ and $33 \%$, respectively [2], which compares unfavourably with B-cell lymphoid neoplasms [24].

International Prognostic Index (IPI) was originally developed to prognosticate B-cell lymphoma patients. It has been used in T-cell lymphoma patients, but its applicability in them has been doubted [5]. Definitely, there is a need of a reliable prognostic model to stratify this group of patients.

Various attempts were made to improve the dismal outcome of T-cell lymphomas. These include different combinations of conventional chemotherapy, novel agents, high-dose therapy, and allogeneic stem cell transplantation. Despite all these advances, cyclophosphamide, doxorubicin, vincristine, and prednisolone- (CHOP-) like therapy are still the standard first-line treatment.
This paper looks into the various prognostic markers in T-cell lymphoma as well as the latest updates in its management.

\section{T-Cell Lymphomas: Clinical Characteristics}

Among the nineteen subtypes of T-cell lymphomas, angioimmunoblastic T-cell lymphoma, anaplastic large cell lymphoma, and peripheral T-cell lymphoma not otherwise specified (PTCL-NOS) are the most commonly seen. They each accounts for $20 \%$ to $30 \%$ of all T-cell lymphomas [1]. The median age at presentation is between the fifth and sixth decade with a male predominance, with the exception of ALK-positive anaplastic large cell lymphoma which is usually diagnosed in patients younger than $30[1,6]$.

All T-cell lymphomas behave aggressively except ALKpositive anaplastic large cell lymphoma. They present at an advanced stage, and almost all patients have high IPI scores. A great majority of them had bone marrow and extranodal involvement upon diagnosis. The reported 5-year overall survival and progression-free survival ranged between $32 \%$ to $49 \%$ and $18 \%$ to $36 \%$, respectively [7]. It is important to distinguish cases of ALK-positive anaplastic large cell lymphoma in analysis of T-cell lymphomas because of its exceptional good prognosis. The 5-year overall survival of this group of patients reaches $80 \%[8,9]$. 


\section{Prognostic Markers in T-Cell Lymphoma}

IPI has been the standard prognostic model for B-cell lymphomas for years. It has been applied in T-cell counterparts as well. It stratified anaplastic large cell lymphomas (both ALK positive and ALK negative) and PTCL-NOS into two prognostic groups. The overall survival at 5 years is significantly better in patients with IPI scores less than 1 than those with scores higher than 4 (50\% to $90 \%$ versus $11 \%$ to $33 \%)$ in these two types of T-cell lymphomas [7]. However, IPI cannot differentiate high-risk patients in some rare subtypes of T-cell lymphomas like enteropathy-associated Tcell lymphoma, hepatosplenic T-cell lymphoma, and adult T-cell leukemia/lymphoma. Patients with these lymphomas fared poorly even with a low IPI score. IPI also has limited applicability in angioimmunoblastic T-cell lymphoma because most patients have high IPI scores at presentation $[5,10]$. A prognostic model was specifically developed for PTCL-NOS, the Prognostic Index for PTCL-U, (PIT). It consists of age, performance status, lactate dehydrogenase level, and bone marrow involvement and divides patients into four groups depending on the number of adverse factors they have [11]. It showed a superior predictive power of survival when compared with IPI in this study (log-rank 66.79 versus 55.94). However, even for patients with no adverse factor (i.e., group 1), the 5-year overall survival rate was only $62 \%$. Therefore, it is apparent that a great majority of T-cell lymphoma patients, with the exception of ALK-positive anaplastic large cell lymphoma, have a dismal prognosis irrespective of their prognostic scores.

\section{Advances in Management of T-Cell Lymphomas}

Conventional CHOP-like chemotherapy yields poor response in T-cell lymphomas excluding ALK-positive anaplastic large cell lymphoma. The reported complete remission rate with $\mathrm{CHOP}-\mathrm{like}$ regimens was less than $50 \%$, and the 5 -year overall survival ranged from $26 \%$ to $45 \%[4,12,13]$. This result is certainly inferior to B-cell lymphomas even prior to the era of Rituximab. The use of anthracycline does not bring any improvement in outcome either $[4,7]$. A recent trial reported that the addition of etoposide to CHOP improved event-free survival in young patients with ALK-positive anaplastic large cell lymphomas (event-free survival at 3 years $91.2 \%$ versus $57.1 \%, P=.012$ ), but the overall survival was not significantly different. There was a trend towards a better event-free survival in the remaining T-cell lymphoma patients, but it did not reach statistical significance (3-year event-free survival $60.7 \%$ versus $48.3 \%, P=.057)$ [14].

\section{Intensive Chemotherapy Regimens}

Intensive chemotherapy did not produce improvement in treatment results in this group of patients. GELA (Groupe d'Etudes des Lymphomes) showed that intensive
ACVBP regimen (doxorubicin, cyclophosphamide, vindesine, bleomycin, and prednisolone) was better than $\mathrm{CHOP}$ in terms of overall survival and event-free survival (5-year overall survival rates $46 \%$ versus $38 \%(P=.036)$ and 5-year event-free survival $39 \%$ versus $29 \%(P=.007)$ ). However, only $15 \%$ of the total 635 patients had T-cell lymphomas, and the outcome of this subgroup of patients was not reported separately [16]. In studies that only included T-cell lymphoma patients, none of them showed that dose-intense therapy improved outcome. In fact, a subsequent report by GELA group showed that ACVBP was not superior to conventional CHOP in treatment of angioimmunoblastic T-cell lymphoma patients [5]. MD Anderson group compared $\mathrm{CHOP}$ with intensive regimens (hyper-CHOP, hyper-CVAD, and alternating triple therapy) in $135 \mathrm{~T}$-cell lymphoma patients (including 40 anaplastic large cell lymphoma patients). There was no significant difference in overall survival as well as complete remission rates between the two groups. Similar results were obtained when the patients with anaplastic large cell lymphoma were excluded from analysis [15]. Table 1 summarized the results of these studies. In conclusion, there was so far no regimen shown to be superior to $\mathrm{CHOP}$ in the literature.

\section{High-Dose Therapy and Autologous Stem Cell Transplantation}

Studies evaluating the role of autologous stem cell transplantation in treatment of T-cell lymphomas showed conflicting results. Autologous stem cell transplantation failed to improve survival for angioimmunoblastic T-cell lymphoma patients in a GELA study. However, the disease status of patients at transplantation was not known [5]. The same group reported another study comparing the outcome of aggressive lymphomas with either autologous stem cell transplantation or chemotherapy consolidation. They received induction chemotherapy followed by consolidation with either autologous stem cell transplantation or chemotherapy if they achieved complete remission. They did not find any significant difference in remission rates and survival in the subgroup of patients with nonanaplastic T-cell lymphoma [17]. A recent study in Germany also found that frontline high-dose therapy (Mega CHOP plus etoposide) with autologous stem cell transplantation had complete remission rate of less than $50 \%$ in patients with nonanaplastic $\mathrm{T}$ cell lymphomas [18]. The overall survival and event-free survival at 3 years were $25.9 \%$ (95\% C.I. $10.4 \%-41.4 \%$ ) and $44.5 \%$ (95\% C.I. $26.5 \%-62.5 \%)$, respectively, which was significantly worse than B-cell counterparts. Moreover, in 33 T-cell lymphoma patients enrolled in this study, only 22 patients $(66.7 \%)$ were able to undergo autologous stem cell transplantation as per protocol. The majority of early dropouts was due to disease progression during therapy.

On the contrary, some better results were reported when autologous stem cell transplantation was done in first complete remission. A retrospective study in Spain showed the 5-year overall survival rate and progressionfree survival rate of $68 \%$ and $63 \%$, respectively, when 
TABLE 1: Summary of various treatment results of T-cell lymphomas.

\begin{tabular}{|c|c|c|c|c|c|c|c|c|c|}
\hline Author & Year & $\begin{array}{l}\text { No. of } \\
\text { patients }\end{array}$ & ALK + ve ALCL & Regimens & CR & ORR & OS & EFS & Ref \\
\hline $\begin{array}{l}\text { Lopez-Guillermo } \\
\text { et al. }\end{array}$ & 1998 & 174 & $\begin{array}{l}30 \text { (ALK status not } \\
\text { known) }\end{array}$ & $\begin{array}{l}120 \text { CHOP } 54 \text { not } \\
\text { specified }\end{array}$ & $49 \%$ & $64 \%$ & $\begin{array}{c}38 \% \\
\text { (at } 4 \text { years) }\end{array}$ & Not available & {$[4]$} \\
\hline Armitage et al. & 1989 & 134 & Not known & $\begin{array}{l}80 \text { CHOP-like } 54 \\
\text { not specified }\end{array}$ & $50 \%$ & $\begin{array}{c}\text { Not } \\
\text { available }\end{array}$ & $\begin{array}{c}45 \% \\
\text { (at } 4 \text { years) }\end{array}$ & Not available & {$[12]$} \\
\hline Rudiger et al. & 2002 & 129 & 0 & $\begin{array}{l}90 \text { CHOP-like } 39 \\
\text { not specified }\end{array}$ & $\begin{array}{c}\text { Not } \\
\text { available }\end{array}$ & $\begin{array}{c}\text { Not } \\
\text { available }\end{array}$ & $\begin{array}{c}26 \% \\
\text { (at } 5 \text { years) }\end{array}$ & $\begin{array}{c}20 \% \\
\text { (at } 5 \text { years) }\end{array}$ & [13] \\
\hline Schmitz et al. & 2010 & 343 & 78 & $\begin{array}{l}122 \text { CHOP } 221 \\
\text { CHOEP }\end{array}$ & $\begin{array}{c}\text { Not } \\
\text { available }\end{array}$ & $\begin{array}{c}\text { Not } \\
\text { available }\end{array}$ & $\begin{array}{l}53.9 \%-67.5 \% \\
\text { (at } 3 \text { years) }\end{array}$ & $\begin{array}{c}41.1 \%-50.0 \% \\
\text { (at } 3 \text { years) }\end{array}$ & [14] \\
\hline Mourad et al. & 2008 & 157 & 0 & $\begin{array}{l}\text { ACVBP + } \\
\text { CHOP-like } \\
\text { regimens }\end{array}$ & $46 \%$ & $\begin{array}{c}\text { Not } \\
\text { available }\end{array}$ & $\begin{array}{c}33 \% \\
\text { (at } 5 \text { years) }\end{array}$ & $\begin{array}{c}29 \% \\
\text { (at } 5 \text { years) }\end{array}$ & {$[5]$} \\
\hline Escalon et al. & 2005 & 24 & 0 & $\mathrm{CHOP}$ & $58 \%$ & $\begin{array}{c}\text { Not } \\
\text { available }\end{array}$ & $\begin{array}{c}43 \% \\
\text { (at } 3 \text { years) }\end{array}$ & Not available & [15] \\
\hline Escalon et al. & 2005 & 52 & 0 & HyperCVAD like & $59 \%$ & $\begin{array}{c}\text { Not } \\
\text { available }\end{array}$ & $\begin{array}{c}49 \% \\
\text { (at } 3 \text { years) }\end{array}$ & Not available & [15] \\
\hline
\end{tabular}

autologous stem cell transplantation was done in first complete remission [19]. However, $31 \%$ of the patients were anaplastic large cell lymphomas, and the status of ALK expression was not known. Even when anaplastic large cell lymphomas were excluded from analysis, the overall survival and progression-free survival rate at 5 years were $61 \%$ and $55 \%$, respectively, which is remarkably better than the results obtained with conventional chemotherapy. The same group reported a superior outcome with autologous stem cell transplantation as consolidation for patients with peripheral T-cell lymphoma (excluding cases with ALKpositive anaplastic large cell lymphoma), who achieved a complete or partial remission after induction chemotherapy in a prospective trial [20]. The complete remission rate was $89 \%$ after autologous stem cell transplantation, and the overall survival and progression-free survival were $73 \%$ and $53 \%$, respectively, at 3 years. In other prospective trials of 83 patients with T-cell lymphomas, autologous stem cell transplantation was done in 55 of enrolled patients who achieved at least a partial remission after induction chemotherapy. The complete remission rate after stem cell transplantation was $78 \%$, and the overall survival at 3 years was $71 \%$ [21]. In two prospective studies done by an Italian group, 46 (74\%) of 62 enrolled patients underwent autologous stem cell transplantation as consolidation after they achieved complete remission with induction chemotherapy. After a median followup of 76 months, the estimated overall survival and event-free survival at 12 years were $34 \%$ and $30 \%$, respectively. When patients with ALK-positive anaplastic large cell lymphomas are excluded, the overall and event-free survival at 12 years dropped to $21 \%$ and $18 \%$, respectively [22].

Based on these retrospective and prospective studies, it seems that autologous stem cell transplantation is beneficial if it is done in first complete remission and when the disease is chemosensitive. Unfortunately, it is apparent that a significant number of patients have progression early in disease course such that autologous stem cell transplantation is not feasible at all. It is therefore the challenge how to improve the complete remission rate in nonanaplastic T-cell lymphomas and how to salvage patients who do not respond to frontline induction chemotherapy.

\section{Novel Agents}

Alemtuzumab is a humanized monoclonal anti-CD 52 antibody. CD 52 is expressed by both T-cells and B-cells. It was shown to produce superior remission rate (complete remission of $71 \%$ ) when alemtuzumab was combined with $\mathrm{CHOP}$ as frontline treatment in a group of 24 patients with peripheral T-cell lymphomas (none of the them were ALKpositive anaplastic large cell lymphoma) [23]. The median duration of complete remission was 11 months. However, there was a high incidence of infectious complications despite anti-infective prophylaxis. The marked immunosuppression associated with alemtuzumab is a major issue that needs to be addressed when this antibody is administered.

Gemcitabine, a pyrimidine analogue, was studied in peripheral T-cell lymphomas either as single agent $[24,25]$ or combination treatment $[26,27]$ in both frontline and salvage setting. An overall response rate from $51 \%$ to $77 \%$ was achieved. It was well tolerated with mainly haematological toxicity reported. However, only a small number of patients were enrolled in each of these studies, and well-designed randomized controlled trials are needed before its role is defined in T-cell lymphoma management.

Pralatrexate is a new folate antagonist which is structurally similar to methotrexte but with greater affinity for one carbon-reduced folate carrier, and hence it is selectively accumulated in malignant cells. Both in vitro and in vivo data demonstrated superior efficacy of pralatrexate compared with methotrexate $[28,29]$. It was demonstrated to have activity in peripheral T-cell lymphomas with an overall response rate of 54\% achieved in a phase II study [30]. In the largest prospective study of relapsed or refractory peripheral T-cell lymphomas, Pralatrexate in Relapsed or Refractory 
Peripheral T-cell Lymphoma (PROPEL), an overall response rate of $29 \%$ was seen in 109 heavily pretreated patients, and the median duration of response was 9.4 months [31]. The main toxicity reported was mucositis and cytopenia, both of which were manageable. This result is impressive and led to its approval by Food and Drug Administration for treatment of relapsed or refractory peripheral T-cell lymphoma.

Histone deacetylase inhibitors are also shown to have activities in T-cell lymphomas. Vorinostat and romidepsin are approved by FDA for treatment of cutaneous T-cell lymphoma. A phase II study of romidepsin in 48 relapsed or refractory peripheral T-cell lymphoma patients found an overall response rate of $31 \%$ and a median duration of response of 9 months [32]. Ongoing studies are underway to evaluate the activity of this group of agents in peripheral T-cell lymphomas.

Apart from the above agents, there are some early results of novel agents such as mTOR (mammalian target of rapamycin) inhibitors [33], monoclonal antibodies antiCD30 [34], and anti-CD4 [35] that they may be active in T-cell lymphomas. In addition, proteosome inhibitor bortezomib [36], purine analogue clofarabine [37], and lenalidomide [38] are also reported to be useful in Tcell lymphomas. However, more clinical trials on them are necessary before their efficacy in T-cell lymphoma management is determined.

\section{Allogeneic Stem Cell Transplantation}

There are encouraging results of allogeneic stem cell transplantation in management of peripheral T-cell lymphoma. European Group for Blood and Marrow Transplantation reported a retrospective study of 45 angioimmunoblastic Tcell lymphoma patients who received at least two lines of chemotherapy prior to study entry. They showed that the 3year overall survival rate and progression-free survival rate of these heavily pretreated patients were $64 \%$ and $54 \%$, respectively [39]. The cumulative incidence of relapse at 3 years was only $20 \%$, and the cumulative incidence of nonrelapse mortality at 12 months after transplantation was $25 \%$. The development of chronic graft-versus-host disease was associated with a lower incidence of relapse, but the difference did not reach statistical significance. Patients with chemosensitive diseases had a significantly better outcome (overall survival at 3 years $81 \%$ versus $64 \%, P=.002$; progression-free survival at 3 years $66 \%$ versus $53 \%, P=$ .004). Another study from France which included $77 \mathrm{~T}$ cell lymphoma patients undergoing allogeneic stem cell transplantation showed that the 5-year overall survival and event-free survival rate were $57 \%$ and $53 \%$, respectively [40]. Better overall and event-free survival at 5 years was observed in those transplanted in complete or partial remission than patients with chemoresistant diseases (5-year overall survival $69 \%$ versus 29\%; 5-year event-free survival $64 \%$ versus $27 \%, P=.0002$ ). Two patients in this study relapsed and achieved a second complete remission after donor lymphocyte infusion. Both of them had remained in remission for at least two years after donor lymphocyte infusion. In addition,
$26 \%$ of patients in this study underwent reduced intensity conditioning (RIC) allogeneic stem cell transplantation, and they showed a trend of longer event-free survival and less transplant-related mortality in univariate analysis $(P=$ .108 and .107 resp.). This suggested a significant role of graft-versus-lymphoma effect in T-cell lymphomas. In fact, RIC allogeneic stem cell transplantation is an attractive option, particularly in patients who are heavily pretreated, aged, or with comorbidities. Some favourable results of RIC allogeneic stem cell transplantation in T-cell lymphomas are reported. In a prospective trial in Italy, 17 patients with peripheral T-cell lymphomas underwent RIC allogeneic transplantation. The overall survival and progression-free survival at 3 years were $81 \%$ and $64 \%$, respectively, while the nonrelapse mortality was only $6 \%$ at 2 years [41]. Another recently published study done in United States showed a slightly inferior outcome with the overall survival and progression-free survival at 3 years of $59 \%$ and $53 \%$, respectively, while the nonrelapse mortality at 3 years was $19 \%$ [42]. However, the median age of patients enrolled in this study was 57 (compared with median age of 41 in the former study), and a larger proportion of patients had chemoresistant disease at transplantation. Notwithstanding, based on the above results, RIC allogeneic transplantation appears to be a feasible and effective treatment option with acceptable toxicity for T-cell lymphomas.

\section{Conclusion}

T-cell lymphomas are a heterogeneous group of diseases but are uniformly aggressive and respond poorly to our conventional chemotherapy, with the notable exception of ALK-positive anaplastic large cell lymphoma. Some advances were made in its treatment in recent years, and some novel agents show early promising results.

Allogeneic stem cell transplantation should be considered in patients with poor-risk disease, and RIC extended this option to the older, more heavily pretreated patients. It is hoped that with the availability of novel agents, we are able to bring more patients into complete remission before transplantation and improve their outcome.

\section{References}

[1] "Mature T-cell and NK-cell neoplasms," in WHO Classification of Tumours and Haematopoietic and Lymphoid Tissues, S. H. Swerdlow, E. Campo, N. L. Harris et al., Eds., pp. 270-319, International Agency for Research on Cancer, Lyon, France, 2008.

[2] C. Gisselbrecht, P. Gaulard, E. Lepage et al., "Prognostic significance of T-cell phenotype in aggressive non-Hodgkin's lymphomas. Groupe d'Etudes des Lymphomes de l'Adulte (GELA)," Blood, vol. 92, no. 1, pp. 76-82, 1998.

[3] A.-L. Cheng, Y.-C. Chen, C.-H. Wang et al., "Direct comparisons of peripheral T-cell lymphoma with diffuse B-cell lymphoma of comparable histological grades—should peripheral T-cell lymphoma be considered separately?" Journal of Clinical Oncology, vol. 7, no. 6, pp. 725-731, 1989. 
[4] A. López-Guillermo, J. Cid, A. Salar et al., "Peripheral T-cell lymphomas: initial features, natural history, and prognostic factors in a series of 174 patients diagnosed according to the R.E.A.L. classification," Annals of Oncology, vol. 9, no. 8, pp. 849-855, 1998.

[5] N. Mourad, N. Mounier, J. Brière et al., "Clinical, biologic, and pathologic features in 157 patients with angioimmunoblastic T-cell lymphoma treated within the Groupe d'Etude des Lymphomes de l'Adulte (GELA) trials," Blood, vol. 111, no. 9, pp. 4463-4470, 2008.

[6] S. Ascani, P. L. Zinzani, F. Gherlinzoni et al., "Peripheral T-cell lymphomas. Clinico-pathologic study of 168 cases diagnosed according to the R.E.A.L. classification," Annals of Oncology, vol. 8, no. 6, pp. 583-592, 1997.

[7] J. M. Vose, M. Neumann, and M. E. Harris, "International peripheral T-cell and natural killer/T-cell lymphoma study: pathology findings and clinical outcomes international T-cell lymphoma project," Journal of Clinical Oncology, vol. 26, no. 25, pp. 4124-4130, 2008.

[8] R. D. Gascoyne, P. Aoun, D. Wu et al., "Prognostic significance of anaplastic lymphoma kinase (ALK) protein expression in adults with anaplastic large cell lymphoma," Blood, vol. 93, no. 11, pp. 3913-3921, 1999.

[9] R. L. Ten Berge, J. J. Oudejans, G.-J. Ossenkoppele et al., "ALK expression in extranodal anaplastic large cell lymphoma layouts systemic disease with (primary) nodal involvement and a good prognosis and occurs before dissemination," Journal of Clinical Pathology, vol. 53, no. 6, pp. 445-450, 2000.

[10] L. De Leval, C. Gisselbrecht, and P. Gaulard, "Advances in the understanding and management of angioimmunoblastic Tcell lymphoma," British Journal of Haematology, vol. 148, no. 5, pp. 673-689, 2010.

[11] A. Gallamini, C. Stelitano, R. Calvi et al., "Peripheral T-cell lymphoma unspecified (PTCL-U): a new prognostic model from a retrospective multicentric clinical study," Blood, vol. 103, no. 7, pp. 2474-2479, 2004.

[12] J. O. Armitage, J. P. Greer, A. M. Levine et al., "Peripheral T-cell lymphoma," Cancer, vol. 63, no. 1, pp. 158-163, 1989.

[13] T. Rüdiger, D. D. Weisenburger, J. R. Anderson et al., "Peripheral T-cell lymphoma (excluding anaplastic largecell lymphoma): results from the non-Hodgkin's lymphoma classification project," Annals of Oncology, vol. 13, no. 1, pp. 140-149, 2002.

[14] N. Schmitz, L. Trumper, M. Ziepert et al., "Treatment and prognosis of mature T-cell and NK-cell lymphoma: an analysis of patients with T-cell lymphoma treated in studies of the German High-Grade Non-Hodgkin's Lymphoma Study Group (DSHNHL)," Blood. In press.

[15] M. P. Escalón, N. S. Liu, Y. Yang et al., "Prognostic factors and treatment of patients with T-cell non-Hodgkin lymphoma: the M.D. Anderson Cancer Center Experience," Cancer, vol. 103, no. 10, pp. 2091-2098, 2005.

[16] H. Tilly, E. Lepage, B. Coiffier et al., "Intensive conventional chemotherapy (ACVBP regimen) compared with standard $\mathrm{CHOP}$ for poor-prognosis aggressive non-Hodgkin lymphoma," Blood, vol. 102, no. 13, pp. 4284-4289, 2003.

[17] N. Mounier, C. Gisselbrecht, J. Brière et al., "All aggressive lymphoma subtypes do not share similar outcome after frontline autotransplantation: a matched-control analysis by the Groupe d'Etude des Lymphomes de l'Adulte (GELA)," Annals of Oncology, vol. 15, no. 12, pp. 1790-1797, 2004.

[18] M. Nickelsen, M. Ziepert, S. Zeynalova et al., "High-dose CHOP plus etoposide (MegaCHOEP) in T-cell lymphoma: a comparative analysis of patients treated within trials of the
German High-Grade Non-Hodgkin Lymphoma Study Group (DSHNHL)," Annals of Oncology, vol. 20, no. 12, pp. 19771984, 2009.

[19] J. Rodríguez, E. Conde, A. Gutiérrez et al., "The results of consolidation with autologous stem-cell transplantation in patients with peripheral T-cell lymphoma (PTCL) in first complete remission: the Spanish Lymphoma and Autologous Transplantation Group experience," Annals of Oncology, vol. 18, no. 4, pp. 652-657, 2007.

[20] J. Rodríguez, E. Conde, A. Gutiérrez et al., "Frontline autologous stem cell transplantation in high-risk peripheral T-cell lymphoma: a prospective study from the Gel-Tamo Study Group," European Journal of Haematology, vol. 79, no. 1, pp. 32-38, 2007.

[21] P. Reimer, T. Rüdiger, E. Geissinger et al., "Autologous stemcell transplantation as first-line therapy in peripheral tcell lymphomas: results of a prospective multicenter study," Journal of Clinical Oncology, vol. 27, no. 1, pp. 106-113, 2009.

[22] P. Corradini, C. Tarella, F. Zallio et al., "Long-term follow-up of patients with peripheral T-cell lymphomas treated up-front with high-dose chemotherapy followed by autologous stem cell transplantation," Leukemia, vol. 20, no. 9, pp. 1533-1538, 2006.

[23] A. Gallamini, F. Zaja, C. Patti et al., "Alemtuzumab (Campath$1 \mathrm{H})$ and CHOP chemotherapy as first-line treatment of peripheral T-cell lymphoma: results of a GITIL (Gruppo Italiano Terapie Innovative nei Linfomi) prospective multicenter trial," Blood, vol. 110, no. 7, pp. 2316-2323, 2007.

[24] P. L. Zinzani, F. Venturini, V. Stefoni et al., "Gemcitabine as single agent in pretreated T-cell lymphoma patients: evaluation of the long-term outcome," Annals of Oncology, vol. 21, no. 4, pp. 860-863, 2009.

[25] S. Sallah, J. Y. Wan, and N. P. Nguyen, "Treatment of refractory T-cell malignancies using gemcitabine," British Journal of Haematology, vol. 113, no. 1, pp. 185-187, 2001.

[26] J. G. Kim, S. K. Sohn, Y. S. Chae et al., "CHOP plus etoposide and gemcitabine (CHOP-EG) as front-line chemotherapy for patients with peripheral T cell lymphomas," Cancer Chemotherapy and Pharmacology, vol. 58, no. 1, pp. 35-39, 2006.

[27] H.-T. Arkenau, G. Chong, D. Cunningham et al., "Gemcitabine, cisplatin and methylprednisolone for the treatment of patients with peripheral T-cell lymphoma: the Royal Marsden Hospital experience," Haematologica, vol. 92, no. 2, pp. 271$272,2007$.

[28] E. S. Wang, O. O'Connor, Y. She, A. D. Zelenetz, F. M. Sirotnak, and M. A. S. Moore, "Activity of a novel anti-folate (PDX, 10propargyl 10-deazaaminopterin) against human lymphoma is superior to methotrexate and correlates with tumor RFC-1 gene expression," Leukemia and Lymphoma, vol. 44, no. 6, pp. 1027-1035, 2003.

[29] L. E. Toner, R. Vrhovac, E. A. Smith et al., "The scheduledependent effects of the novel antifolate pralatrexate and gemcitabine are superior to methotrexate and cytarabine in models of human non-hodgkin's lymphoma," Clinical Cancer Research, vol. 12, no. 3, pp. 924-932, 2006.

[30] O. A. O'Connor, S. Horwitz, P. Hamlin et al., "Phase II-III study of two different doses and schedules of pralatrexate, a high-affinity substrate for the reduced folate carrier, in patients with relapsed or refractory lymphoma reveals marked activity in T-cell malignancies," Journal of Clinical Oncology, vol. 27, no. 26, pp. 4357-4364, 2009.

[31] O. O'Connor, B. Pro, and L. L. Pinter-Brown, "Results of the pivotal, multicenter, phase II study of pralatrexate in 
patients with relapsed or refractory peripheral T-cell lymphoma (PTCL)," Journal of Clinical Oncology, vol. 27, no. 15, supplement, 2009, abstract no. 8561.

[32] R. L. Piekarz, "Phase II trial of single agent romidepsin in relapsed peripheral T cell lymphoma," in Proceedings of the 50th Annual American Society of Hematology, 2009, abstract no. 14157.

[33] P. B. Johnston, S. M. Ansell, J. P. Colgan et al., "mTOR inhibition for relapsed or refractory Hodgkin lymphoma: promising single agent activity with Everolimus (RAD001)," in Proceedings of the ASH Annual Meeting, p. 110, 2007, abstract no. 2555.

[34] N. L. Bartlett, A. Younes, M. H. Carabasi et al., "A phase 1 multidose study of SGN-30 immunotherapy in patients with refractory or recurrent $\mathrm{CD} 30^{+}$hematologic malignancies," Blood, vol. 111, no. 4, pp. 1848-1854, 2008.

[35] F. D’Amore, J. Radford, T. Relander et al., "Phase II trial of zanolimumab (HuMax-CD4) in relapsed or refractory noncutaneous peripheral T cell lymphoma," British Journal of Haematology, vol. 150, no. 5, pp. 565-573, 2010.

[36] J. Lee, C. Suh, H. J. Kang et al., "Phase I study of proteasome inhibitor bortezomib plus CHOP in patients with advanced, aggressive T-cell or NK/T-cell lymphoma," Annals of Oncology, vol. 19, no. 12, pp. 2079-2083, 2008.

[37] S. Horwitz, D. Mulford, H. Paul et al., "Clofarabine is active in peripheral T-cell lymphomas: results of the phase I portion of a phase I/II study," Annals of Oncology, vol. 19, supplement 4, p. iv157, 2008, abstract no. 244.

[38] G. S. Dueck, N. Chua, A. Prasad et al., "Activity of lenalidomide in a phase II trial for T-cell lymphoma: a report on the first 24 cases," Journal of Clinical Oncology, vol. 27, no. 15, supplement, 2009, abstract no. 8524.

[39] C. Kyriakou, C. Canals, J. Finke et al., "Allogeneic stem cell transplantation is able to induce long-term remissions in angioimmunoblastic T-cell lymphoma: a retrospective study from the lymphoma working party of the European Group for Blood and Marrow Transplantation," Journal of Clinical Oncology, vol. 27, no. 24, pp. 3951-3958, 2009.

[40] S. Le Gouill, N. Milpied, A. Buzyn et al., "Graft-versuslymphoma effect for aggressive T-cell lymphomas in adults: a study by the Société Française de Greffe de Moëlle et de Thérapie Cellulaire," Journal of Clinical Oncology, vol. 26, no. 14, pp. 2264-2271, 2008.

[41] P. Corradini, A. Dodero, F. Zallio et al., "Graft-versuslymphoma effect in relapsed peripheral T-cell non-Hodgkin's lymphomas after reduced-intensity conditioning followed by allogeneic transplantation of hematopoietic cells," Journal of Clinical Oncology, vol. 22, no. 11, pp. 2172-2176, 2004.

[42] A. R. Shustov, T. A. Gooley, B. M. Sandmaier et al., "Allogeneic haematopoietic cell transplantation after non-myeloablative conditioning in patients with T-cell and natural killer-cell lymphoma," British Journal of Haematology, vol. 150, pp. 170178, 2010. 


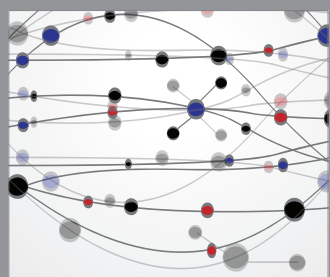

The Scientific World Journal
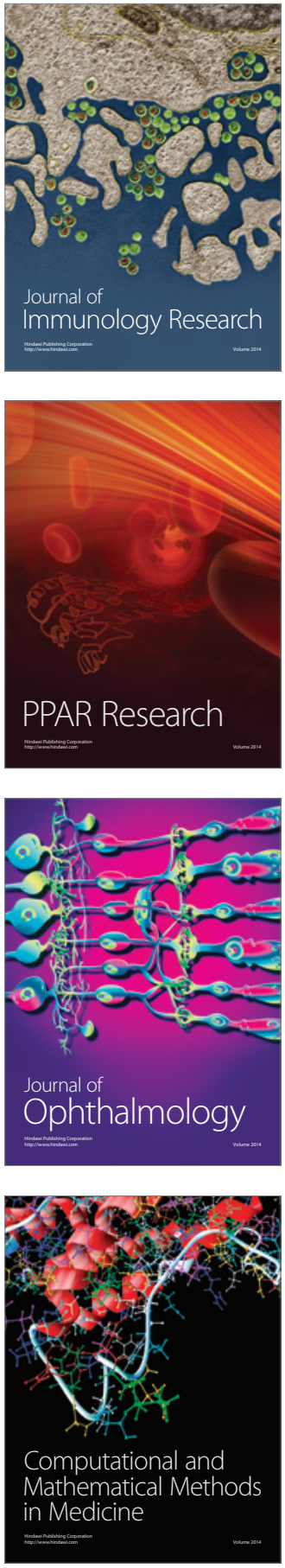

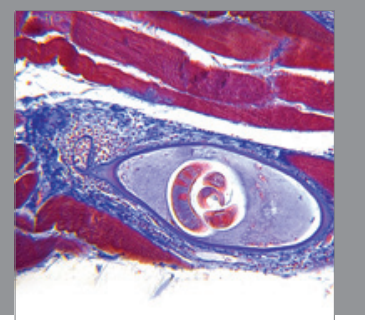

Gastroenterology

Research and Practice
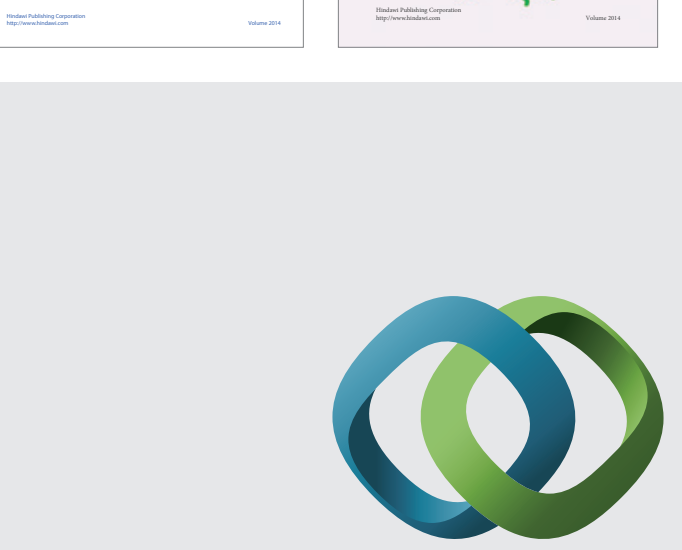

\section{Hindawi}

Submit your manuscripts at

http://www.hindawi.com
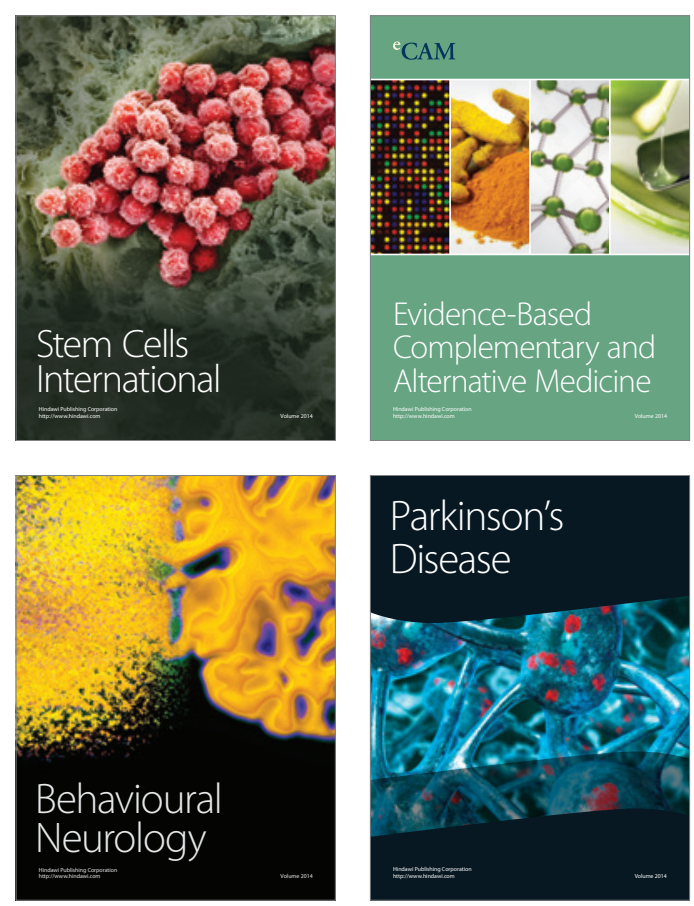

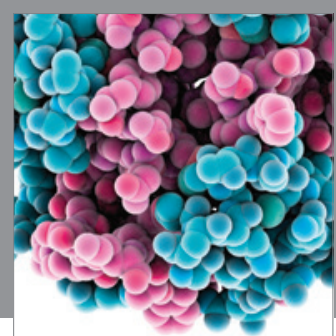

Journal of
Diabetes Research

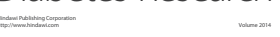

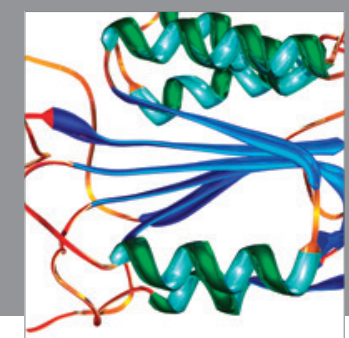

Disease Markers
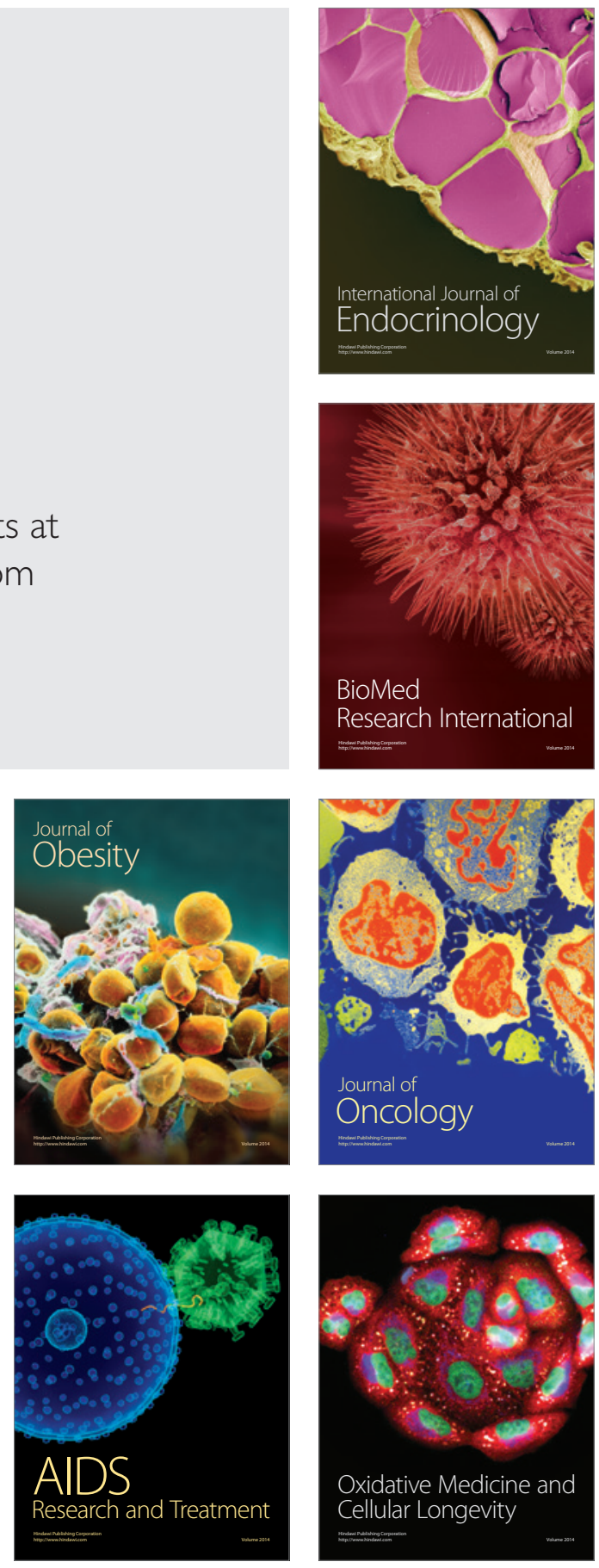